\title{
SUATU TELAAH LESBIAN, GAY, BISEKSUAL, TRANSGENDER (LGBT) DALAM PERSPEKTIF HUKUM POSITIF
}

\author{
Oleh : YULIANA SURYA GALIH, S.H., M.H. *)
}

\begin{abstract}
The case of the famous celebrities SJ, adds to the long list, cases of sexual violence against children. Case SJ who commit violence against the child who is the son of lacquer DS-men, has been bothering everyone to be alert to LGBT.

LGBT as a form of sexual perversion, behavioral and appearance does not match their gender, has expanded its social tantan normal society, including also resulted in loss of children.

If the deviant sexual behavior conducted by LGBT people has caused the victims, especially children, is a criminal offense, the criminal provisions other than regulated in the Criminal Code, also when the victims were children then apply the provisions set forth in Law No. 23 of 2002 on Child Protection as amended and supplemented by Law No. 35 of 2014 on Amendments to the Law No. 23 of 2002 on Child Protection.

Transgender is a form of deviant behavior and appearance does not match their gender. Against this transgender, Law No. 23 of 2006 provides the legal space to do a sex change to apply to the determination of the District Court.
\end{abstract}

\section{ABSTRAK}

Kasus yang menimpa selebritis kondang SJ, menambah daftar panjang, kasus kekerasan seksual terhadap anak. Kasus SJ yang melakukan kekerasan anak terhadap DS yang merupakan anak lak-laki, telah mengusik semua orang untuk lebih mewaspadai kaum LGBT.

LGBT sebagai bentuk penyimpangan seksual, penyimpangan perilaku dan penampilan yang tidak sesuai dengan gendernya, telah melakukan ekspansi terhadap masyarakat yang tantan social normal, termasuk pula telah menimbulkan korban terhadap anak-anak.

Apabila perilaku seks menyimpang yang dilakukan oleh kaum LGBT telah menimbulkan korban khususnya anak-anak, adalah merupakan tindak pidana, yang ketentuan pidananya selain diatur didalam KUHP, juga apabila korbannya adalah anak-anak maka berlaku ketentuan yang diatur didalam Undang-undang No. 23 tahun 2002 tentang Perlindungan Anak sebagaimana yang telah diubah dan ditambah dengan Undang-undang No. 35 tahun 2014 tentang Perubahan atas Undang-undang No. 23 tahun 2002 tentang Perlindungan Anak.

Transgender adalah bentuk penyimpangan perilaku dan penampilan yang tidak sesuai dengan gendernya. Terhadap transgender ini, Undang-undang No. 23 tahun 2006 memberikan ruang hukum untuk melakukan perubahan kelamin dengan mengajukan permohonan penetapan ke Pengadilan Negeri.

\footnotetext{
*) Tenaga Pengajar Fakultas Hukum Universitas Galuh
} 


\section{PENDAHULUAN}

Hari-hari kebelakang masyarakat Indonesia tertuju pada pemberitaan yang cukup mendapatkan perhatian publik, yaitu kasus yang menimpa selebritis kondang SAEPUL JAMIL (SJ), yang ditangkap karena diduga telah melakukan kekerasan seksual terhadap anak dibawah umur berinisial DS.

Mungkin tidak pernah terpikirkan oleh setiap seorang, SJ melakukan tindakan asusila terhadap anak dibawah umur, SJ sebagai seorang publik pugur didalam penampilannya tidak menunjukan perilaku menyimpang, apalagi SJ pernah menikah. Menunjukan bahwa SJ adalah orang yang tidak mempunyai masalah dengan perilakunya.

Kasus SJ, telah menjadi perhatian publik, semua lembaga-lembaga pemerintah seperti KPAI, KPI dan lain sebagainya intens mengikuti perkembangan kasus ini, masalahnya bukan hanya korban adalah anak dibawah umur, namun juga keberanian korban untuk melakukan perlawanan dengan cara melaporkan kepada pihak kepolisian adalah merupakan suatu tindakan berani yang patut diapresiasi dan dicontoh oleh siapapun yang merasa telah menjadi korban dari suatu tindak kejahatan. Selama ini anak-anak korban kekerasan terkadang diam, apalagi apabila pelakunya adalah orang yang mempunyai kedudukannya lebih tinggi, orang terpandang dan lain-lain.

Kasus SJ hanyalah sebagaian kecil dari kasus-kasus pelecehan seksual terhadap anak yang mencuat ke permukaan, diluar sana masih banyak kasus-kasus pelecehan seksual, kasuskasus kekerasan terhadap anak yang tidak terungkap atau bahkan dengan sengaja ditutup.

Sekitar setahun lalu kasus kekerasan dan pelecehan seksual terhadap anak yang menghebohkan terjadi di Bali, kematian tragis yang menimpa Engeline masih menjadi buah bibir. Ketidakwajaran dan sejumlah kisah kelam bocah delapan tahun itu bersama ibu angkatnya Margriet Christina Megawe, tetap menyisakan misteri. Kasus kematian Engeline bukan hanya masalah kekerasan dan pelecehan seksual, tetapi juga masalah aturan tentang pengangkatan anak, yang perlu mendapatkan perhatian dari pemerintah.

Kasus lain yang menjadi perhatian publik adalah kasus pelecehan seksual oleh Guru terhadap muridnya di Jakarta Internasional School, kasus Emon yang melakukan sodomi terhadap lebih dari 140 orang anak di Sukabumi dan berbagai macam 
kasus-kasus, kekerasan dan pelecehan seksual terhadap anak yang lainnya.

Anak memang rentan dengan kekerasan, mulai kekerasan dalam keluarga, lingkungan sekolah maupun lingkungan masyarakat. Jumlah angka kekerasan dari tahun ke tahun terus meningkat. Data yang dilansir oleh Komisi Perlindungan Anak Indonesia menyebutkan, dari tahun 2011 sampai dengan tahun 2015 terjadi peningkatan signifikat kekerasan terhadap anak.

Komisi Perlindungan Anak Indonesia (KPAl) menyatakan, kekerasan pada anak selalu meningkat setiap tahun. Hasil pemantauan KPAI dari 2011 sampai 2014, terjadi peningkatan yang sifnifikan. "Tahun 2011 terjadi 2178 kasus kekerasan, 2012 ada 3512 kasus, 2013 ada 4311 kasus, 2014 ada 5066 kasus," kata Wakil Ketua KPAI, Maria Advianti kepada Harian Terbit, Minggu (14/6/2015). (www.kpai.go.id/.../kpaipelaku-kekerasan-terhadap-anak, diakses 28 Feb 2016, 10:45)

5 kasus tertinggi dengan jumlah kasus per bidang dari 2011 hingga april 2015. Pertama, anak berhadapan dengan hukum hingga april 2015 tercatat 6006 kasus. Selanjutnya, kasus pengasuhan 3160 kasus, pendidikan 1764 kasus, kesehatan dan napza 1366 kasus serta pornografi dan cybercrime 1032 kasus.(www.kpai.go.id,ibid).

Dalam kasus SJ, persoalannya bukan hanya terletak pada perbuatan SJ yang telah melakukan kekerasan seksual terhadap anak dibawah umur, akan tetapi juga korbannya seorang anak laki-laki, hal ini menunjukan adanya penyimpangan prilaku yang dilakukan oleh SJ, sehingga menimbulkan pertanyaan apakah SJ seorang gay, padahal selama ini publik mengetahui SJ seorang laki-laki sejati, mantan suami dari penyanyi kondang Dewi Persik.

LGBT merupakan fakta sosial, yang keberadaannya telah ada sejak zaman dahulu. Namun keberadaan LGBT dimasyarakat masih belum bisa diterima, sehingga segala cara dilakukan kaum lesbian, gay, biseksual, dan transgender (LGBT) untuk mendapat pengakuan dan diterima masyarakat. Berbagai media mereka jadikan sebagai alat untuk mengenalkan hubungan sesama jenis ke publik. (ifestyle.okezone.com/ .../cara-lgbtpengaruhi-anak-anak-kenal, diakses 28 Feb 2016, 10:55).

Propaganda LGBT seakan mendapatkan angin segar ketika media televisi sering mempertontonkan seorang laki-laki memerankan peran wanita. Ketika kasus SJ muncul, KPI 
sebagai lembaga yang berwenang untuk melakukan control terhadap semua penayangan televisi, melarang mempertunjukan seorang laki-laki memerankan peran wanita, melalui Surat Edaran No. 203/K/KPI/02/16 pada tanggal 23 Februari 2016.

Hukum sebagai sarana control sosial, telah memberikan sanksi tegas bagi para pelaku kekerasan seksual terhadap anak dibawah umur, sebagaimana yang diatur didalam pasal 292 KUHP, selain pasal tersebut, Undang-undang No. 23 Tahun 2002 tentang Perlindungan Anak sebagaimana telah ditambah dan diubah dengan Undang-undang No. 35 tahun 2014 tentang Perubahan atas Undang-undang No. 23 Tahun 2002 tentang Perlindungan Anak telah mengatur dengan tegas mengenai sanksi bagi pelaku kekerasan seksual terhadap anak.

Selain masalah sanksi pidana terhadap para pelaku kekerasan seksual terhadap anak, dalam hal transgender, didalam Undang-undang 23 tahun 2006 tentang Administrasi Kependudukan, telah diatur mengenai pencatatan peristiwa penting lainnya, salah satu peristiwa penting lainnya mengenai perubahan jenis kelamin yang harus melalui putusan Pengadilan Negeri, namun perubahan jenis kelamin tersebut harus melalui pemeriksaan medis dan pemeriksaan phisikologis terlebih dahulu sebelum mengajukan permohonan ke Pengadilan Negeri.

\section{PEMBAHASAN}

\section{Pengertian LGBT}

LGBT, merupakan kependekan dari singkatan Lesby, Gay, Biseksual dan Transgender, masalah LGBT, dalam tatanan kehidupan masyarakat normal seakan asing, masalah LGBT yang hari-hari kebelakang ramai dibicarakan, bukan hanya sekedar tersandungnya artis kondang SJ yang diduga telah melakukan kekerasan seksual terhadap DS yang merupakan seorang anak laki-laki dibawah umur. Namun kaum LGBT merupakan bagian dari masyarakat yang termarjinalkan.

Istilah LGBT mulai dipakai sekitar tahun 1990-an, istilah LGBT awalnya berasal dari LGB saja, kemudian istilah tambahanpun bermunculan seiring dengan waktu seperti penambahan huruf $Q$ (Queer) menjadi LGBTQ, yang bertujuan untuk menampung orangorang yang masih mempertanyakan identitas seksualnya. Selain menambahkan huruf $Q$ ada pula yang menambahkan huruf I untuk interseks, sehingga menjadi LGBTI, sedangkan di India, ada pula istilah LGBTIH, adanya penambahan huruf $H$. artinya Hijrah, 
yang dipergunakan untuk mereka yang lain sebagai pria, tetapi memiliki identitas gender feminism, bertindak feminism dan memakai pakaian perempuan. (sidomi.com/392791/lgbtadalah lesbian-gay-biseksualtransgender/diakses tanggal 28 Feb 2016 15:55).

Sebelum ada istilah LGBT popular, didalam litelatur ilmiah untuk menyebutkan penyimpangan seksual dimana seseorang menyukai sesama jenis disebut dengan istilah homoseksual, namun perlu dibedakan antara homoseksual yang dilakukan oleh sejenis dengan suatu golongan yang disebut hermaphrodit atau apa yang lazim disebut banci. Di beberapa daerah di Indonesia sering dijumpai hermaphrodit yaitu orang yang berperangai wanita sedang biologisnya adalah pria atau sebaliknya. Di beberapa tempat dapat dijumpai kaum pria yang meniru-niru wanita tetapi sebenarnya dapat disebut banci tiruan. Jika banci yang demikian melakukan sexual inter course terhadap pihak wanita, maka yang terjadi bukanlah suatu homo. Seringkali terjadi bancibanci yang berkeliaran dimalam hari, ada yang mempunyai isteri dan anak. (Gerson W.Bawengan, Pengantar Psikologi Kriminil, 1991:153)
David

Abrahamsen

mengemukakan beberapa tipe dari homoseks tersebut disebut lesbian dan menurutnya ada tiga tipe homoseksual pria, yaitu :

- Tipe aktif yaitu Pria yang melakukan fungsinya sebagai seorang pria.

- Tipe pasif yaitu pria yang menjadi obyek tipe pertama.

- Tipe campuran, yaitu sewaktu-waktu bersikaf aktif dan sewaktu-waktu bersikap pasih.

Ketiga tipe seperti itu juga terdapat pada lesbian.

\section{a. Lesbi}

Lesbi adalah ketertarikan seorang wanita kepada wanita lainnya. lesbi adalah hubungan yang terjalin nyata antara perempuan dengan perempuan. Dimana satu berperan sebagai laki-laki dan yang satunya lagi berperan sebagai perempuan. Biasanya perempuan yang berperan menjadi seorang laki-lakinya, adalah perempuan yang berpenampilannya "tomboy".

Pada umumnya pelesbi akan berpenampilan selayaknya laki-laki bagi pelesbi yang menyamar jadi laki-laki. Dan yang perempuan pun akan berdandan serba feminism. Untuk pelesbi yang berperan laki-laki sering diantara mereka akan punya tindik di kupingnya, di bibirnya atau di dalam 
lidahnya. Gaya rambutnya akan sengaja dibuat selaki-laki mungkin. (www.kompasiana.com/.../begini-caralesbian-menyalurkan-hasratnya, diakses tanggal 28 Feb 2016, 20:31).

Jauh sebelum peradaban modern, lesbi sudah ada sejak ribuan tahun silam. Kata lesbi berasal dari kata Lesbos, yaitu sekitar tahun 580 sebelum masehi di Timur Yunani telah berkembang sebuah mitos tentang kisah cinta antara putri Sappho yang berasal dari kalangan elit dengan murid wanitanya bernama Athis di Pulau Lesbos, dari pulau Lesbos itulah kemudian dikenal lesbian untuk homoseksual wanita. (Sarlito Wirawan Sarwono, Psikologi Remaja, 2000:180).

Kaum lesbi di Indonesia, sekarang lebih terbuka, hal ini sebagai akibat dari pengaruh media social seperti Facebook, apabila didalam Facebook, menemukan nama yang berujungnya ada kata "less" itu menunjukan bahwa wanita tersebut adalah lesbi dan biasanya hanya mau berteman dengan wanita saja.

\section{b. Gay}

Istilah gay digunakan secara umum untuk menggambarkan seorang pria yang tertarik secara seksual dengan pria lain dan menunjukkan komunitas yang berkembang diantara orang-orang yang memiliki orientasi seksual yang sama. Caroll (2005) mengatakan bahwa orientasi seksual merupakan ketertarikan seseorang pada jenis kelamin tertentu secara emosional, fisik, seksual dan cinta. (www.landasanteori. com > Psikologi, diakses tanggal 28 Feb 2016, 21:40)

Dalam masyarakat-masyarat dimana homoseksualitas dilarang oleh hokum atau oleh norma-norma yang lain memang homoseksualitas berkembang menjadi kejatahan atau masalah social maupun masalah pribadi. Akan tetapi tidak selamanya masyarakat menganggap homoseksualitas ini sebagau suatu hal yang negative. Norton Hunt, seorang pakar pada tahun 1979 menulis sebuah buku berjudul Gay What you should know about homosexuality, menyatakan bahwa 2400 tahun yang lalu di Ahtena Yunani, homoseksualitas merupakan tradisi yang lazim dilakukan oleh orang-orang dari kalangan terhormat. Bahkan bangsa Sparta di barat daya Yunani, yang terkenal gagah dan ahli perang, juga merupakan orang-orang yang melakukan praktek homoseksual. (Sarlito Wirawan Sarwono, 2000:180).

Di Indonesia homoseksualitas juga menjadi kelaziman di beberapa masyarakat tertentu seperti yang terjadi di daerah Ponorogo, dimana remaja- 
remaja pria yang berparas tampan menjadi partner seksual (mereka disebut gemblakan) dari para warok (jagoan-jagoan). Begitu juga dalam catatan sejarah kerajaan Giri yang bersumber dari Kitab Jatiswara yang digubah atas kehendak Kanjeng Gusti Adipati Anom pada tahun 1742, terdapat kisah-kisah dan riwayat-riwayat yang menggambarkan praktek-praktek homoseksual dikalangan masyarakat biasa maupun para bangsawan. (Sarlito Wirawan Sarwono, ibid).

Homoseksual yang dilakukan oleh laki-laki dengan laki-laki atau gay, telah ada sejak zaman nabi Luth, yaitu persetubuhan antara laki-laki dengan laki-laki, melalui dubur yang dilakukan oleh masyarkat kota Sodom, kemudian perbuatan homoseksual tersebut dikenal dengan sebutan sodomi. Kisah perbuatan sodomi yang dilakukan oleh masyarakat Sodom merupakan perbuatan homoseksual yang pertama kali dalam sejarah umat manusia, kisah kaum nabi Luth tersebut diriwayatkan didalam Al Quran Surat Al A'raaf juz 8 ayat 80-85.

Komunitas gay terus berkembang untuk mendapatkan pengakuan didalam masyarakat, di Amerika komunistas gay, seakan mendapatkan pengakuan ketika Mahkamah Agung Amerika Serikat melegalkan pernikahan sejenis, lebih dari 50 negara bagian.

(archives.portalsatu.com/

opini/waspada-ledakan-lgbt,diakses tanggal 11 Mar 2016, 21:18)

Facebook sebagai salah satu media social ikut memberikan peran yang cukup besar bagi perkembangan komunitas gay dan komunitas homoseksual pada umumnya, facebook memakai fultur pelangi enam warna yang merupakan bendera symbol kaum LGBT. Dalam sejarahnya, bendera pelangi ini dibuat oleh Gilbert Baker, seniman San Fransisco pada tahun 1978. Ketika itu ia menyanggupi permintaan seorang gay, Harvey Milk untuk mendesain bendera mendukung hak-hak kaum gay.(sidomi.com, diakses tanggal 28 Feb 2008, 15:55).

\section{c. Biseksual}

Biseksual adalah orientasi seksual yang menunjukkan ketertarikan seseorang terhadap orang lain tanpa memperdulikan gender. Seorang pelaku biseksual biasanya tidak memperdulikan seseorang itu pelaku heteroseksual, homoseksual ataupun transgender. Biseksual bias digolongkan sebagai perilaku seksual yang sering kali orientasi seksnya berubah-ubah. Orang dari segala usia, ras budaya dan agama yang berlainan itdak menghalangi seseorang untuk menjadi pelaku 
biseksual. (ramuanabe.com, blog, diakses tanggal 03 Mart 2016, 21:00).

Krafft-Ebing, salah seorang seksologis Jerman menyebut biseksual dengan sebutan psychosexual hermaphroditism yaitu eksistensi dua seks biologis dalam satu spesies atau kejadian yang merupakan kebetulan dari karakteristik pria dan wanita dalam satu tubuh (Bowie dalam Storr, 1999). Ellis (dalam Storr, 1999) kemudian meninggalkan istilah psychosexual hermaphroditism dan memperluas makna dari biseksual sebagai hasrat seksual untuk pria maupun wanita yang dialami oleh individu. Menurut Freud (1905), biseksual merupakan kombinasi dari maskulinitas dan feminitas, sedangkan menurut Stekel (1920) dan Klein (1978), biseksual bukanlah merupakan kombinasi dari maskulinitas dan femininitas melainkan heteroseksualitas dan homoseksualitas (dalam Storr, 1999). (repository.usu.ac.id/bitstream/1234567 89/29510/3/Chapter\%20ll.pdf, diakses tanggal tanggal 03 Mart 2016, 21:35)

Dalam pengertian umumnya, biseksual adalah orientasi seksual yang mempunyai ciri-ciri berupa ketertarikan estetis, cinta romantis, dan hasrat seksual kepada pria dan wanita. Menurut Masters (1992), biseksual adalah istilah untuk orang yang tertarik secara seksual baik itu terhadap laki-laki maupun perempuan. Biseksual juga didefinisikan sebagai orang yang memiliki ketertarikan secara psikologis, emosional dan seksual kepada laki-laki dan perempuan (Robin \& Hammer, 2000 dalam Matlin, 2004). (repository.usu.ac.id/bitstream/ 123456789/29510/3/Chapter\%2011.pdf, diakses tanggal tanggal 03 Mart 2016, 21:35).

\section{d. Transgender}

Transgender adalah orang yang cara berperilaku atau penampilanya tidak sesuai dengan peran gender pada umumnya. Transgenfer adalah orang yang dalam berbagai level "melanggar" norma kultural mengenai bagaimana seharusnya pria dan wanita itu. Seorang wanita, misalnya secara kultural dituntut untuk lebih lembut. Kalau pria yang berkarakter demikian,itu namanya transgender. Orang-orang yang lahir dengan alat kelamin luar yang merupakan kombinasi pria-wanita juga termasuk transgender. Transgender ada pula yang mengenakan pakaina lawan jenisnya,baik sekali maupun rutin. Perilaku transgenderlah yang mungkin membuat beberapa orang mengganti jenis kelaminya, seperti pria menjadi wanita begitu pula sebaliknya. (www.kompasiana.com/fauziarizal/ 
mengenal lebihdekat-transgender, diakses tanggal 04 Mart 2016,16:42)

Istilah ini transgender (TG) dipopulerkan pada tahun 1970 (tapi tersirat pada tahun 1960) menggambarkan orang-orang yang ingin hidup cross-gender tanpa operasi pergantian seks Pada tahun 1980-an. istilah ini diperluas untuk istilah payung dan menjadi populer sebagai sarana menyatukan semua identitas gender mereka yang tidak cocok dengan jenis kelamin mereka ditugaskan saat lahir. (artikel-terbaik.

blogspot.com/

.../sejarah-transgender-dunia-dari-masakemasa, diakses tanggal 04 Mar 2016 18:30)

Pada 1990-an, istilah itu pada dimensi politik sebagai sebuah aliansi yang mencakup semua yang telah di beberapa titik tidak sesuai dengan norma-norma gender, dan istilah menjadi digunakan untuk mempertanyakan keabsahan normanorma atau mengejar sama hak dan undang-undang anti-diskriminasi, menuju penggunaan secara luas di media, dunia akademis dan hukum. Istilah ini terus berkembang. (ibid)

Kaum transgender memiliki suatu ketidakpuasan terhadap dirinya sendiri karena merasa tidak adanya kecocokan antara bentuk fisik dan kelamin dengan kejiwaan. Ekspresi orang yang mengalami kebingungan jenis kelamin ini bisa terlihat dalam bentuk dandanan, gaya bicara, tingkah laku, bahkan sampai kepada keinginan untuk melakukan operasi penggantian kelamin (Sex Reassignment Surgery).

\section{Penyimpangan Seksual dalam Hukum Pidana}

Penyimpangan seksual kaum LGBT, sepanjang tidak merugikan orang lain tentu tidak membawa dampak. Baru ada dampak apabila timbul kejahatan dan ada hubungan kausalitas antara penyimpangan seksual dengan kejahatan tersebut.

Beberapa penelitian telah menyebutkan ada hubungan sebab akibat antara penyimpangan seksual dengan tindak kejahatan, seperti yang dikemukakan oleh Dokter David Abrahamsen dalam bukunya the psychology of crime, yang mengemukakan hubungan antara masturbasi dengan nafsu berjudi. Abrahamsen juga menyebutkan ada hubungan kausalitas antara homoseksual dengan tindak kejahatan pembunuhan yang dilakukan oleh Leopold dan Loeb pada tahun 1924. (Gerson W.Bawengan, 1991:149)

Kejahatan yang berhubungan dengan penyimpangan seksual adalah pedofilia, yaitu penyimpangan seksual 
dengan melampiaskan hawa nafsu seksualnya kepada anak-anak dibawah umur.

Pengertian pedofilia adalah
kejahatan seksual yang dilakukan
terhadap anak-anak yang masih
dibawah umur baik terhadap anak laki-
laki maupun anak perempuan.

Hukum Pidana telah mengatur kejahatan yang termasuk pedofilia, yaitu :

Pasal 287 ayat (1) KUHP, yang menyatakan :

Barang siapa bersetubuh dengan seorang wanita di luar perkawinan, padahal diketahuinya atau sepatutnya harus diduganya bahwa umumya belum lima belas tahun, atau kalau umurnya tidak jelas, bawa belum waktunya untuk dikawin, diancam dengan pidana penjara paling lama sembilan tahun.

Pasal Pasal 290 ayat (2) KUHP, yang menyatakan :

Diancam dengan pidana penjara paling lama tujuh tahun :

Barang siapa melakukan
perbuatan cabul dengan seorang
padahal diketahuinya atau
sepatutnya harus diduganya,
bahwa umumya belum lima belas
tahun atau kalau umumya tidak
jelas, yang bersangkutan belum
waktunya untuk dikawin;
Pasal 290 ayat (3) KUHP, yang
menyatakan:

Barang siapa membujuk seseorang yang diketahuinya atau sepatutnya harus diduganya bahwa umurnya belum lima belas tahun atau kalau umumya tidak jelas yang bersangkutan atau kutan belum waktunya untuk dikawin, untuk melakukan atau membiarkan dilakukan perbuatan cabul, atau bersetubuh di luar perkawinan dengan orang lain.

Pasal 292 KUHP :

Orang dewasa yang melakukan perbuatan cabul dengan orang lain sesama kelamin, yang diketahuinya atau sepatutnya harus diduganya belum dewasa, diancam dengan pidana penjara paling lama lima tahun.

Pasal 293 ayat (1) KUHP :

Barang siapa dengan memberi atau menjanjikan uang atau barang, menyalahgunakan pembawa yang timbul dari hubungan keadaan, atau dengan penyesatan sengaja menggerakkan seorang belum dewasa dan baik tingkah lakunya untuk melakukan atau membiarkan dilakukan perbuatan cabul dengan dia, padahal tentang belum kedewasaannya, diketahui atau selayaknya harus diduganya, diancam dengan pidana penjara paling lama lima tahun.

Kejahatan seksual dengan melampiaskan kepuasan seksualnya kepada anak laki-laki diatur secara khusus didalam pasal 292 KUHP. Selain termasuk pedofilia, penyimpangan seksual dengan melakukan hubungan 
seksual dengan sesama laki-laki atau disebut sodomi.

Sodomi, yaitu hubungan seksual melalui dubur/ anus yang dilakukan oleh sesama jenis kelamin yaitu laki-laki dengan laki-laki dan seperti yang telah diuraikan tersebut di atas kata sodomi itu sendiri berasal dari kata Sodom yaitu nama kota pada zaman nabi Luth, dimana kaum nabi Luth melakukan perbuatan sodomi.

Selain ketentuan dalam pasalpasal tersebut di atas, untuk melindungi anak dari berbagai macam kekerasan dan ekploistasi terhadap anak, pemerintah telah mengeluarkan Undang-undang No. 23 tahun 2002 tentang Perlindungan Anak yang telah diubah dan ditambah dengan Undangundang No. 35 tahun 2014. Didalam ketentuan pidana yang diatur didalam pasal 81 Undang-undang No. 35 tahun 2014 ancaman pidananya lebih berat dibandingkan dengan ketentuan yang ada didalam pasal 81 dan pasal 82 Undang-undang No. 23 tahun 2002.

Didalam pasal 81 Undangundang No. 23 tahun 2002 yang menyatakan :

Setiap orang yang dengan sengaja melakukan kekerasan atau ancaman kekerasan memaksa anak melakukan persetubuhan dengannya atau dengan orang lain, dipidana dengan pidana penjara paling lama 15 (lima belas) tahun dan paling singkat 3 (tiga) tahun dan denda paling banyak Rp $300.000 .000,00$ (tiga ratus juta rupiah) dan paling sedikit $\mathrm{Rp}$ $60.000 .000,00$ (enam puluh juta rupiah).

Kemudian pasal 82 Undangundang No. 23 tahun 2002, menyatakan :

Setiap orang yang dengan sengaja melakukan kekerasan atau ancaman kekerasan, memaksa, melakukan tipu muslihat, serangkaian kebohongan, atau membujuk anak untuk melakukan atau membiarkan dilakukan perbuatan cabul, dipidana dengan pidana penjara paling lama 15 (lima belas) tahun dan paling singkat 3 (tiga) tahun dan denda paling banyak Rp 300.000.000,00 (tiga ratus juta rupiah) dan paling sedikit Rp 60.000.000,00 (enam puluh juta rupiah).

Ketentuan didalam Undangundang No. 35 tahun 2014, yaitu :

\section{Pasal 76D}

Setiap Orang dilarang melakukan Kekerasan atau ancaman Kekerasan memaksa Anak melakukan persetubuhan dengannya atau dengan orang lain.

\section{Pasal 76E}

Setiap Orang dilarang melakukan Kekerasan atau ancaman Kekerasan, memaksa, melakukan tipu muslihat, melakukan serangkaian kebohongan, atau membujuk Anak untuk melakukan atau 
membiarkan dilakukan perbuatan cabul.

Ketentuan pidana dari larangan sebagaimana tersebut didalam pasal 76D dan 76E Undang-undang No. 35 tahun 2014, terdapat didalam pasal 81 yaitu :

(1) Setiap orang yang melangggar ketentuan sebagaimana dimaksud dalam Pasal 76D dipidana dengan pidana penjara paling singkat 5 (lima) tahun dan paling lama 15 (lima belas) tahun dan denda paling banyak Rp. 5.000.000.000,00 (lima miliar rupiah).

(2) Ketentuan pidana sebagaimana dimaksud pada ayat (1) berlaku pula bagi Setiap Orang yang dengan sengaja melakukan tipu muslihat, serangkaian kebohongan, atau membujuk Anak melakukan persetubuhan dengannya atau dengan orang lain.

Dari ketentuan pidana tersebut di atas terdapat perubahan mengenai ancaman pidana dari aturan sebelumnya, namun walaupun ketentuan pidana sudah diperberat akan tetapi tindak pidana kekerasan terhadap anak masih tinggi dari tahun ke tahun sebagaimana laporan yang dilansir oleh KPAI.

Tindak pidana kekerasan terhadap anak yang di atur didalam Undang-undang No. 23 tahun 2002 sebagaimana telah diubah dan ditambah dengan Undang-undang No. 35 tahun 2014, tidak memandang apakah pelaku itu adalah seorang gay, lesbi dan lain-lain, yang jelas unsur pokok dari ketentuan undang-undang tersebut yaitu korban adalah anak-anak. Berlainan dengan pasal 292 KUHP telah dengan jelas dan tegas menyebutkan selain dibawah umur, antara pelaku dengan korban harus sesama jenis kelamin, dengan demikian dia bisa seorang gay atau seorang lesbi.

\section{LGBT dalam hubungannya dengan} Administrasi Kependudukan

Didalam Undang-undang No. 23 tahun 2006 tentang Administrasi Kependudukan, tidak dikenal istilah Lesbi, Gay, Biseksual dan Transgender (LGBT). LGBT suatu kata yang popular untuk menyebut orang-orang yang perilaku seksual menyimpang, walaupun secara fisik dia wanita akan tetapi hanya tertarik kepada wanita saja (Lesbi) demikian pula sebaliknya seorang lakilaki hanya tertarik kepada laki-laki (Gay) dia demikian pula dengan biseksual, suatu bentuk penyimpangan seksual, terkadang dia suka sama lawan jenis tapi juga suka sesama jenis sedangkan transgender tidak adanya kesesuaian antara fisik dan gender dengan perilaku dan penampilannya. 
Transgender sebagai bentuk penyimpangan berperilaku atau penampilanya tidak sesuai dengan peran gender pada umumnya dan mereka yang memiliki kombinasi jenis kelamin pria dan wanita, memungkinkan untuk dilakukan perubahan jenis kelamin. Peluang untuk mengubah jenis kelamin ini telah ditentukan didalam pasal 56 ayat (1) Undang-undang No. 23 tahun 2006, yang menyatakan :

Pencatatan Peristiwa Penting
lainnya dilakukan oleh Pejabat
Pencatatan Sipil atas permintaan
Penduduk yang bersangkutan
setelah adanya penetapan
pengadilan negeri yang telah
memperoleh kekuatan hukum
tetap.

Penjelasan pasal 56 ayat (1) Undang-undang Nomor 23 Tahun 2006, menyebutkan :

Yang dimaksud dengan
"Peristiwa Penting lainnya"
adalah peristiwa yang ditetapkan
oleh pengadilan negeri untuk
dicatatkan pada Instansi
Pelaksana, antara lain perubahan
jenis kelamin.

Dari ketentuan pasal tersebut dengan jelas menentukan bahwa perubahan jenis kelamin hanya bisa dilakukan dengan terlebih dahulu mengajukan permohonan penetapan ke Pengadilan Negeri. Beberapa perkara permohonan perubahan jenis kelamin,

telah diputus dan dikabulkan oleh Pengadilan Negeri diantaranya Penetapan Pengadilan Negeri Soasiu No. 05/Pdt.P/2014/PN.Sos, Penetapan Pengadilan Negeri Kabupaten Semarang di Unggaran No. 518/Pdt.P/ 2013/PN.Ung.

Penetapan Pengadilan Negeri tersebut menunjukan bahwa perubahan jenis kelamin telah ditentukan oleh Undang-undang No 23 tahun 2006, akan tetapi untuk melakukan perubahan jenis kelamin tersebut, diperlukan pemeriksaan baik medis maupun psikhologis.

Bahwa berdasarkan urian tersebut di atas, di dalam Undangundang No 23 tahun 2006, tidak dikenal adanya istilah lesbi, gay, biseksual dan transgender, akan tetapi orang-orang yang termasuk dalam kelompok transgender dan kombinasi gender, bisa dimungkin untuk melakukan perubahan jenis kelamin, sehingga ada kesesuaian antara gender yang dimilikinya dengan prilaku dan penampilan.

LGBT bukanlah sesuatu hal yang baru didalam kehidupan masyarakat, namun seiring dengan kemajuan dunia informasi, telah mengubah cara pandang masyarakat, sehingga komunitas LGBT mendapatkan ruang gerak yang leluasa untuk mengkampanyekan kaumnya. Melalui 
media social kaum LGBT melakukan ekspansinya kepada masyarakat yang tatanan kehidupannya normal.

Kasus SJ hanyalah sebagian kecil dari kasus-kasus penyimpangan seksual. Masih banyak kasus-kasus kekerasan seksual dan progaganda kaum LGBT telah dilakukan sampai merambah ke dunia anak-anak. Anakanak Indonesia harus mendapatkan perhatian khusus bukan saja pemerintah, akan tetapi semua pihak, harus berperan aktif.

\section{KESIMPULAN}

Lesbi, Gay, Biseksual dan Transgender (LGBT) merupakan bentuk penyimpangan seksual. LGBT merupakan fakta sosial yang terjadi di masyarakat, kaum LGBT ingin mendapatkan pengakuan sehingga komunitas mereka diakui keberadaannya ditengah-tengah masyarakat.

Orang-orang yang termasuk dalam kelompok LGBT, bukanlah orangorang yang jahat, namun apabila penyimpangan seksual tersebut dilakukan terhadap anak-anak atau pedofilia berlaku ketentuan sebagaimana diatur didalam Undangundang Nomor 23 Tahun 2002 tentang Perlindungan anak sebagaimana diubah dan ditambah dengan Undang-undang
Nomor 35 Tahun 2014 tentang Perubahan atas Undang-undang Nomor 23 Tahun 2002 tentang Perlindungan Anak.

Bagi orang-orang yang termasuk transgender maupun kombinasi jenis kelamin laki-laki dan wanita, berdasarkan Undang-undang Nomor 23 Tahun 2006 tentang Administrasi Kependudukan, ada ruang hukum untuk melakukan perubahan jenis kelamin, melalui permohonan penetapan melalui Pengadilan Negeri.

\section{DAFTAR PUSTAKA}

\section{Buku :}

Marpaung, Leden, Kejahatan Terhadap Kesusilaan, dan Masalah Prevensinya, Sinar Grafika, Jakarta, 1996.

Prinst, Darwan, Hukum Anak Indonesia, PT. Citra Aditya Bakti, Bandung, 1997.

Sarwono, Sarlito Warawan, Psikologi Remaja, Rajawali Pers, Jakarta, 2000.

Simandjuntak, B, Pengantar Kriminologi dan Patalogi Sosial, Tersito, Bandung, 1981.

W.Bawengan, Gerson, Pengantar Psikologi Kriminil, PT.Pradnya Paramita, Jakarta, 2000.

\section{Undang-undang :}

Soesilo, R. Terjemahan. Kitab UndangUndang Hukum Pidana beserta 
Lengkap Dengan KomentarKomentarnya Pasal demi Pasal. Politea. Bogor. 1991.

Undang-undang No. 23 tahun 2002 tentang Perlindungan Anak sebagaimana telah diubah dan ditambah dengan Undang-undang No. 35 tahun 2014 tentang Perubahan atas Undang-undang No. 23 tahun 2002 tentang Perlindungan Anak.

Undang-undang No. 23 tahun 2006 tentang Administrasi Kependudukan.

\section{Internet :}

archives.portalsatu.com/ opini/waspadaledakan-lgbt,diakses tanggal 11 Mar 2016, 21:18).

artikel-terbaik. blogspot.com/ .../sejarahtransgender-dunia-dari-masakemasa, diakses tanggal 04 Mar 2016 18:30

lifestyle.okezone.com/ pengaruhi-anak-anak-kenal, diakses 28 Feb 2016, 10:55.

putusan.mahkamahagung.go.id, diakses tanggal 06 Mart 2016, 19:30.

ramuanabe.com , blog, diakses tanggal 03 Mart 2016, 21:00

repository.usu.ac.id/bitstream/12345678 9/29510/3/Chapter\%20II.pdf,diak ses tanggal tanggal 03 Mart 2016, 21:35

Sidomi.com/392791/lgbt-adalah-lesbiangay-biseksualransgender,diakses tanggal 28 Feb 2016, 15:55 www.kpai.go.id/.../kpai-pelakukekerasan-terhadap-anak, diakses 28 Feb 2016, 10:45.

www.kompasiana.com/.../begini-caralesbian-menyalurkan-hasratnya, diakses tanggal 28 Feb 2016, $20: 3$

www.landasanteori. com, Psikologi, diakses tanggal 28 Feb 2016, $21: 40$

www.kompasiana.com/fauziarizal/ mengenal lebihdekattransgender, diakses tanggal 04 Mart 2016,16:42. 